Kaja Kaźmierska (i)

University of Lodz, Poland

\title{
Winners and Losers of the Process of Transformation as an Etic Category versus Emic Biographical Perspective
}

DOI: http://dx.doi.org/10.18778/1733-8077.15.4.11

Abstract One of the common and schematic descriptions in the perspective of the 1989 breakthrough are two ways of dealing with it by people who are respectively called winners or losers of transformation. These stereotypical characteristics are not only the tool to draw the general image of effects of the transition, but are also based on the specific way of interpretation deeply rooted, for example, in neoliberal thinking. Yet, from the perspective of an individual-so-called Schütz's man on the street-the categorization of winners and losers not only simplifies the description of social reality, but also it cannot be easily biographically justified because the etic categorization is not always relevant to the emic perspective. In other words, the life history of an individual, showing the main phases and events of biography, and life story-the way that one interprets his/her biographical experiencesmay not correspond to each other. The analysis of these two aspects of biography (what is lived through and how it is interpreted) shows how people have dealt with the process of transformation In the paper, it is presented on the basis of one case study.

Keywords Biographical Analysis; Emic; Etic; Process of Transformation

Kaja Kaźmierska, PhD, Professor at the University of Lodz, head of the Department of Sociology of Culture, Faculty of Economics and Sociology at the University of Lodz, Poland, and director of the Institute of Sociology. She specializes in biographical research, identity, and biographical memory. The author of books: Polish Wartime Experiences and Shaping of Ethnic Identity. Analysis of Borderline Narratives (IFiS PAN, Warsaw 1999), Biography and Memory: The Generational Experience of the Shoah Survivors (Academ-

ic Studies Press, Boston 2012). She has edited a selection of
Ssues related to the great transformation change 1 of the social system in relation to all aspects of social life (economic, political, cultural) over the last three decades have become the subject of interest of sociologists, economists, historians, lawyers, and other representatives of social sciences. No wonder, since Polish society as one of many and, at the same time, the largest in Central and Eastern Europe has undergone a radical change in the political and economic system. The dynamics of research on this process have been subordinated to the specific time frame and attempts to define when the transformation processes came to an end. As far as the first point of time reference is concerned, it was determined by anniversaries celebrated from 1989, which (also to some extent conventionally, because changes in the economic system started earlier) is symbolically described as a turning point and the beginning of a great change. Thus, we had to deal with publications analyzing the effects of transformation, for example, after 10 or 20 years (just to name a few examples: Giza-Poleszczuk, Marody, and Rychard 2000; Marody 2000a; Kochanowicz and Marody 2010; Kozłowski and Domański 2010).

It turned out to be much more difficult to define the end of the transition process. It is difficult to set a specific date here, although some scholars believe that Poland's accession to the European Union may be considered as another great opening for social processes related more to modernization than already achieved transition from the old to the new political system. For example, Mirosława Marody suggested (2004:9), “We assumed that 14 years after the introduction of fundamental political reforms, the work of systemic transformation could be considered completed, while the foreground is the question of the direction and pace of civilization changes."

On the other hand, four years earlier, Andrzej Rychard (2000:11) wrote, "when one sometimes hears voices that the transformation has in fact ended, one can only agree with them in the sense that a certain stage of political and institutional transformations has ended. Whereas social transformation-in fact, social change-continues because it is a continuous process and runs according to a different chronology than a political one." Such perspective is much closer to the biographical approach presented here, where macro social processes are reflected in the life experiences of individuals, who, on the one hand, become their subjects and, on the other hand, by giving meaning to their actions, are interpreters and creators of social reality. In this respect, we can still analyze, even after 30 years, social results of transformation.

The starting point for the analyses presented below is my understanding of a more complex meaning of transformation as a process that cannot be definitively closed within a defined time frame. In other words, if other criteria, such as the transition to the capitalist and democratic systems, are taken into account, these changes can be placed in the period 1989-2004, whereas the transformation "continues" through the biographical consequences for the actors who have experienced it in the perspective of the individual life cycle. These were the assumptions of the research project "Experience of the Process of the Transformation in Poland. A Sociological 
Comparative Analysis Based on Biographical Perspective," in which we conducted autobiographical narrative interviews with people born in the 1960s, 1970s, and 1980s. ${ }^{1}$ One may say that those born in the 1980s have nothing in common with the process, yet, in the research project, we try to show the sequential processual transition of social reality which consequences on different levels can be identified in individual biographies. ${ }^{2}$

In this paper, I would like to discuss just one issue related to the question how we may describe the process of dealing with the transformation changes by individuals. The query how people cope with this big social change involves the desire to estimate whether they managed the new social, political, and economic conditions successfully or they experienced failures. As a result of such thinking two terms-winners and losers-of transformation appeared both in the scientific and public discourse. We cannot forget that the process of systemic transformation from the very beginning has become the topic of not only scientific research, but also public, media, and political discourses. Due to the limited space of this text, I do not analyze how, when, and by whom winner/loser categories have been used in the public and, especially, political discourse. Thus, I do not intend to analyze the complicated field where great and rapid economy

This article was prepared within the project "Experience of the Process of the Transformation in Poland. A Sociological funded by the National Science Center in Poland, the NCN project number UMO-2013/09/B/HS6/03100. A short descripproject number UMO-2013/09/B/HS6/03100. A short descripthe Great Change. The Process of Social Transformation in Poland in Biographical Research Perspective(s) (Kaźmierska in this volume). See articles by Katarzyna Waniek, Joanna Wygnańska, Jacek Burski in this volume. and social changes have been discussed, evaluated, and still remain a token in political discourses concentrated on the effects of once chosen economy solutions, what we could observe in contemporary political discussions.

My point in this paper is that these are etic categories used to describe and interpret individual and group ways of dealing with systemic transformation. Analysis of biographical narrative interviews with people who experienced the time of the big change at different phases of life and coming from various social environments and milieus shows that the winner/loser categorization is not necessarily the emic perspective when understanding strategies of individuals coping with the new reality. I use Kenneth Pike's (1967:37) terms well established in contemporary anthropological, as well as sociological reflection: "etic viewpoint studies behavio as from outside of a particular system," while the "emic viewpoint results from studying behavior as from inside the system."

I begin the text from referring to the sense and meaning of terms winners and losers which appear in some Polish research. Then, I am going to present a case study-a biographical narrative interview with a woman anonymized as Róża. This analysis is divided into two sections. In the first section, her life history will be described; in the second one, Róża's life story. I use here "an analysis concept where the distinction between life story and life history (i.e. between the narrated personal life as related in conversation or written in the present time and the lived-through life) plays a central role" (Rosenthal 2004:49). The life history based on lived-through life enables reconstructing the past-the dynamic of events experienced by an individual, while the life story allows us to show the past and present interpretations of these experiences. I will try to show that concentrating only on the life history aspect of the analyzed narrative can be misleading in the process of interpretation and can easily legitimate using etic thus imposed categories like, for instance, winners or losers. In conclusions, I show both methodological and analytical aspects of the presented study

\section{Winners and Losers as Etic Categories}

One of the common and schematic descriptions in the perspective of the 1989 breakthrough are two ways of dealing with it by people who are respectively called winners or losers of transformation. Differentiation between beneficiaries and victims is another way of describing the social and biographical situation of individuals representing certain social groups. It is not easy to discuss these characteristics in neutral language since both dyads are evaluative as such and, additionally, they are usually used in relation to specific frames of interpretation deeply rooted in different discourses.

The first dyad-beneficiaries and victims-highlights more the role of external social frames. According to Zdzisław Pisz (2000:112-113), "Beneficiaries are individuals who have been enabled to advance, sometimes rapidly, socially, and economically, by the transformation program and its implementation. The victims, on the other hand, are individuals and social groups whose professional and social careers were interrupted or clearly delayed by the transfor- mation process in relation to potential opportunities stemming from the adjustment capital." According to the author, politically and economically designed circumstances have made some individuals and/ or social groups put in privileged positions-they could take advantage of the transformation. At the same time, other people, due to the same processes, have been excluded from the access to differently defined goods and paid huge biographical and social costs. Moreover, they have been subjected to processes they could hardly control or influence. This way of describing social phenomena and processes may be considered as a normative one. Its supporters usually focus on social injustice and such design of macro structural frames that neglected people's abilities and possibilities to cope with the new economic deal. Those who are beneficiaries have taken advantages thanks to positions as members of politically, socially, or economically privileged groups. Those who are victims have paid the costs of transformation like losing social position, means for leaving, what has resulted in an increased feeling of insecurity and awareness of new divisions and inequalities in society. ${ }^{3}$

When examining different Polish sociological publications devoted to the process of transformation, especially from the time of the first two decades, we may observe that many authors focused on broadly understood social costs of transformation, social exclusion, developing inequalities and dangers generated by social and economic change (e.g.

${ }^{3}$ This kind of rhetoric is used by socially left oriented perspectives, especially in political discourse. Paradoxically enough, it is also used by contemporary right wing parties, as well as PIS 
Tarkowska 2000; Bugaj 2010; Pańków 2010; Sadowski 2010). What is interesting, in my opinion, is that these critical voices were rather hardly heard in public and media discourses. One example is the research on urban poverty carried out by sociologists in Lodz since 1992. They undertook research on communities threatened with social exclusion as a result of pauperization processes. Lodz has become a natural area of research. Over twenty years of research practice has led to the establishment of the Lodz School for Research on Poverty and Social Welfare (Golczyńska-Grondas and Potoczna 2016:384). ${ }^{4}$

Social change has more frequently been introduced as a challenging, difficult, yet commonly profitable process. A lot of prominent social researchers promoted this approach consequently supporting the dynamic of social change and more or less consciously adapting the neoliberal perspective of social reality interpretation. We can see it in published studies and, moreover, learn from contemporary voices of researchers and intellectualists who took an active part in creating, maintaining, and legitimating a certain type of this discourse which we can generally characterize as neoliberal (e.g., Król 2015; Giza-Poleszczuk 2018).

According to Giza-Poleszczuk (2018), “We [sociologists] believed that it was our obvious duty not only to describe modernization, but also to actively support it, as Solidarity was previously advocated.

${ }^{4}$ Although this research gained recognition in the sociological community, it was difficult for it to reach the local authorities, which even blamed the researchers for "promoting" Lodz as a city of poverty.
Therefore, as sociologists, we were one of the most committed promoters of the new Central European order. All these Western ideas-such as meritocracy, post-industrialism, and development theories-were then uncritically accepted by us, because they came to us from a different, better world. They were an obvious counterbalance to socialism, so they had to be good." The consequence of such thinking could be the application of winners/losers categorization in order to describe the dynamics of social change and people's activities: "There was a venturesome middle class and "marauders," that is, farmers from state-owned farms (so-called PGRs) or large industrial plants. The latter were treated in a careless way, in terms of clumsy people who, having supplied the rod, could not use it rationally. Instead of being blamed for the aggressive transformation, all the blame was placed on those who simply exceeded the limits of the transformation" (Giza-Poleszczuk 2018). This diagnosis of (self)sociologist way of thinking expressed in the interview from 2018 can be easily recognized in researcher's works.

Winner/loser category was very supportive in this context. First of all, if we compare winners/losers categorization with beneficiaries/victims, the first one is focused more on an individual agency-those who win or lose are defined as actors of the game let it be labor market, the project of one's professional career, or generally-biography. So, implicitly, when this categorization is used, some dose of responsibility is being taken into account. In other words, both winners and losers are considered as individuals who did something or resigned to do anything in order to find themselves in a new social and economic system.
We may recognize this categorization in many works as a straightforwardly or implicitly used tool to describe social reality. At this point, it is not my aim to provide the reader with a full review of literature and authors. I have chosen these few examples because, in my opinion, these authors can be identified as important and opinion-forming voices in the discussion about transformation. Their work was a synthesis of empirical research and theory building on transformation as a social change. An additional argument in favor of referring to the research is the confrontation with the current critical voice of the already quoted Giza-Poleszczuk (2018). So, just to give the example-winner/loser categorization can be found in the study from 2000 where the authors (Giza-Poleszczuk, Marody, and Rychard 2000) try to nuance the typology $y^{5}$ by showing that there is a wide gap between winners and losers, which is filled by those who, due to certain circumstances, may in the future find themselves in one or the other group. Their distinction is possible due to the introduction of two criteria: possessing (or lacking) resources, as well as knowledge and/or ignorance of the rules, that is, the degree of rationality. In this way, apart from clearly defined categories of winners and losers, the authors introduce additional ones: those who do not have resources and know that they cannot win and those who do have them, but do not know that they can use them, that is, win. The latter group is interesting in particular, because they are people who are not aware of the capitalization of their resources. In other words, as the authors point out,

I consciously use the term typology because the authors smoothly change the winner//losers categorization into typology by developing its subtypes. such groups of people may feel discomfort because it is difficult for them to determine whether they have benefited or lost from the system change (Giza-Poleszczuk, Marody, and Rychard 2000:3738). This interesting and sophisticated analysis is anyway based on the assumption that the category of winners and losers can objectively describe individual attitudes and ways of dealing with the new system, and although the authors suggest that they do not intend to use normative terms, in fact they do. ${ }^{6}$

Five years later, the categorization of winners or losers was even more legitimated by using it in a book title. In 2005, Maria Jarosz edited the book entitled Winners and Losers of Polish Transformation. The very book cover deserves commentary. It is a piece of Canaletto painting presenting an aristocracy woman in a carriage and people belonging to other, certainly lower, classes in the background. I do not know what was the key for the cover, but if understood straightforwardly-the synonym of winner is the person who is well-off and keeps a privileged position in society.

Even more intriguing are comments in the introduction where Jarosz used the terms winner, losers, and beneficiaries. She rather avoided the word

${ }^{6}$ It is interesting that also in 2000 in another publication Mirostawa Marody (2000b:77) wrote, "in the case of categories defining basic social groups, the dimension that synthesizes the most fundamental transformations within the meanings associated with them, and at the same time pointcial change, seems to be the division into winners and losers." But, just on the next page she decides to abandon these categories as not describing social mechanisms because they cannot be understood by individual actions, rather by people's motivations, what moves scientific reasoning towards psychological and not sociological analysis. 
victims. Let me quote some small excerpts, for example, "Cost of reforms for different groups is unbearable. It involved different reactions: not only passiveness and despondence, but also a desperate attempt to defend one's affairs" (Jarosz 2005:12); "Passiveness, a sense of injustice, and the lack of fulfillment of claims [not needs] are not simply functions of poverty, but rather the result of systemic transformation that destroys the previous order which was considered as known, normal, and long-lasting" (Jarosz 2005:2-13); "We should remember that the stereotype, so widely spread in common language, of the poor and passive, because disadvantaged ${ }^{7}$ by unfair market economy, is not only a handy tool for political proponents of the losers, but it also is dangerous for the social order and losers themselves. Silent approval for such explanation of the reasons for passiveness, as well as forbearance for poorly justified claims and social promises and attempts to extend welfare activities, more or less straining on public finances-all this may lead to the petrification of passivity and escalation of claims" (Jarosz 2005:15).

The language of scientific description is accompanied here by normative statements with a very clearly expressed neoliberal perspective. As I said in the beginning, it is not easy to describe big social change in neutral language, yet I was quite astonished to read this introduction describing social reality in such an evaluative manner. But, if we could find it in scientific language let alone it has been widely used in political, as well as media and everyday discourses. Thus, stereotyp ical characteristics have not only become the tool to draw the general image of effects of the transition, but have been also absorbed by engaged political discourses such as, for instance, neoliberal thinking. As we know, it promotes individual independence "measured" by such items as creativity, self-development, effectiveness, innovation, self/permanent education, flexibility, agency, self-control, and responsibility, et cetera, and it also evaluates those who are considered as not successful, non-creative at all, or enough, having no abilities to deal with challenging situations, being too passive, et cetera. All these items are framed by one more aspect of neoliberal discourse, that is, the perspective of modernization and patterns of contemporary postmodern reality built in the contrast to traditional/modern society and its values. Although "neoliberal language meets the criteria of quasi-religious rhetoric, it is staged as a result of scientific analyses of organization and management, PR, and marketing" (Czyżewski 2009:93). I will come back to this topic in the conclusions.

When presenting in critical mode the above chosen examples of using winners/losers categories, I do not mean that the intuition of researchers is totally incorrect. Social imagination and sensibility, as well as observation prompt that there are people who have taken advantage and others who, to the contrary, have had big difficulties in dealing with the new reality. We could also show the dynamic of this process, especially considering the exclusion of thousands of people from the labor marke in the 90s and the contemporary common phenom- enon of precarity, especially in the case of young people.

My critical point is that such discourses not only are evaluative, may be excluding, and they simplify the interpretation of the transformation processes, but they also may invalidate other, more complex ways of understanding how individuals managed to deal with the new reality and if, how, in what way they had to reorient themselves in order to adjust to the new economy. Such a point of view justifies my presentation of the above perspective of description of the transformational reality. I have used the texts of the in statu nascendi, that is, the apogee of the transformational processes of the 1990s, to show not only, in my opinion, one of the dominant options of diagnosing social reality, but also to indicate in what circumstances categorization of winners and losers has been shaped. Moreover, I believe that these categories have become so catchy that if they have not dominated, they have certainly framed one of the mainstream ways of thinking about transformation.

Thus, I would like to discuss how, from the perspective of an individual, so-called Alfred Schütz's (1990) man on the street, the categorization of winners and losers not only simplifies the description of social reality, but also it is difficult to be easily biographically justified because the etic perspective is not relevant to the emic one.

I would like to present a biographical narrative interview with a 44-year-old woman living in a small rural commune in Eastern Poland where the un- employment rate in the first decade of 2000 fluctuated between 14 and 20\% ; thus, was much higher and chances for professional development were far more limited than in other parts of the country.

The autobiographical narrative interview was conducted in 2016 within the framework of the aforementioned project in the interviewee's house, and lasted about 2 hours. It is part of a collection of 90 interviews, 30 of which were conducted with people born in the 1970s. I chose this case not to make it "representative" ${ }^{\text {" }}$ of a particular social group or strata, or to show a biography of a woman from a local community that could be considered a kind of periphery. The choice of this case is dictated by the following issues. First of all, on the example of the analysis of this interview, I intend to show how it could be treated as an illustration for the category of winners and losers by referring to literature and adapting a specific analytical perspective, even though these categories do not fit here. Secondly, at first glance, the inclusion of Róża's biography in the transformation process may seem to be an over-interpretation since her professional career begins to crystallize after 2005. I will try to show, in accordance with the logic of biographical experiences, "a narrative 'gestalt' that must be envisioned as an ordered sequence of personal experiences, and that orderliness implies the inner identity development of the biography incumbent" (Schütze 2008:168),

${ }^{8}$ Data according to Statistics Poland. See: https://stat.gov.pl/en/ Retrieved October 18, 2019

I am not referring of couse but to a situation where a case exemplifies certain patterns of experience and biographical strategies in a specific social group. 
showing the continuity between the earlier and the present phases of biography. Thirdly, in the analyzed case, we will probably find unexpected solutions in terms of sources to build social capital by the interviewee.

In the case of Róża, her entry into the labor market in 1995 and a kind of moratorium, that is, safe, although by nature precarious work in an environment of high unemployment risk, allowed her to prepare for later experiences, although this preparation was not fully planned.

The interview is analyzed according to autobiographical narrative interview procedures developed by Fritz Schütze (2008). First, I will reconstruct Róża's life history-chronologically ordered biographical facts and experiences that appear in the narrative. All the data come straightforwardly form the transcription of the interview. In the part of life history, my intention is not to interpret them, but rather to focus on the presented facts and experiences. Then, I present Róża's life story, that is, the way she talks about her life experiences and how she interprets them. This part of work is based on the interview interpretation. As I am going to explain in the next section, this is the analytical division and both aspects are equally important to build the gestalt. Nevertheless, for the purpose of this article, they are characterized separately. It is possible that the reader may get a feeling that some content is repeated in the following two sections, yet, I could not find a better way of clear presentation of both aspects. If done together, it may appear quite complicated to read.

\section{Róża's Life History Reconstructed from Her Narrative}

Róża was born in 1975 in a small rural commune (about 6 thousand inhabitants) in Eastern Poland. She was an only child, partly brought up by her grandmother when both of her parents worked. Her father was a farmer and her mother worked in the post office. Róża's grandmother was a very important significant other for her. After her death in 1991, Róża was 16 years old, her family ties were limited to mother and father relationships. This was the reason she had always dreamed about a big family and, in the future, she wanted to have many children. Róża tried to compensate for the lack of siblings by having a big group of peers, so she could never feel alone. She was a very active member of school and church youth organizations. Thus, she was quickly recognized as a very dynamic person. She was also a good student.

In the third form of secondary school, Róża got to know her future husband. In 1994, in the twelfth grade, she got pregnant, got married, and managed to pass her matriculation exam just before the delivery of her daughter. Considering her new family life situation and the lack of help from her mother who was still working, Róża was not able to continue he education. She decided to postpone her studies to the next year and took care of her baby. She planned to study Polish philology and become a teacher However, in 1995, she got the offer of her first work and she gave up the idea of studying.

Róża became a dentist assistant and started working in the dentist's office placed in her secondary school. The dentist woman who hired Róża is in the narrative consequently called as "my Mrs. Doctor" and "a model of a boss." Róża had worked there for ten years up to 2005

After a half of a year since Róża had started this job, her first son was born, so she had the second child in 1996. She came back to work and, in the meantime, started training related to her work in the field of stomatology and healthcare, as well as she started evening education in postsecondary librarian college. The librarianship study lasted for two and a half years. She undertook the librarian education because of her friend who planned to become a librarian, so Róża simply joined her.

In 2000, her third child (the second son) was born. After a while Róża came back to work in the dentist's office and at the same time started looking for finance resources for individual projects because, in the future, she planned to have an agritourism business. She realized that one could apply for such funding and searched for the opportunities to take part in training on the Internet. She had some capital: a piece of land, ponds, and she wanted to build a house. For four years she had attended various training sessions according to the rule: taking part in training enables writing a project, a business plan, and applying for irreclaimable funding. According to her observation, about $50 \%$ of participants won the project. She was never successful, yet she was determined to be persistent.

At the beginning of 2000, when Róża did not work due to the delivery of her son, she had no mon- ey. ${ }^{10}$ As she said, "I didn't have enough money to buy milk for my child," she started making floral decorations and sold them with her husband in front of the church. She also said that in 2000 her husband was buying milk for the dairy company. So she as well had three cows and, "I had to milk those cows in the morning, help my husband pour the milk, prepare children for kindergarten, and drive them to the kindergarten, and arrive to work at eight."

In 2004, her third son, as the fourth of her children was born. She planned to act according to the wellknown pattern-come back to work after some time would pass from the delivery. Yet, her plans had to be changed. In 2005, her employer "Mrs. Doctor" decided to leave for Great Britain on the wave of post-accession migration. She represented the educated group of Polish migrants (mainly medical professions or engineers) who had a chance to get well paid jobs and immediately improve their economic status. Róża presented her perspective: the dentists' couple rented a small apartment in a block of flats, could raise just one child, had poor perspectives to improve their status. This event may direct our attention to the processes of change initiated by Poland's accession to the European Union. The professional career of Róża is significantly accelerating, although, as we will see, it is difficult to talk about

${ }^{10}$ It is not clear in her story, but we may conclude that her job as a dentist assistant was not based on a permanent contract and it was poorly paid. From the field notes we know that each year her contract was renewed when the docto we may assume that it was still exceptional that the dentist could have an office in the school building as the majority of school offices were closed in Poland at the beginning of 2000. The new regulations since September 2019 obligate school masters to establish a dentist's office. 
the planned, controlled development at the beginning. It should be emphasized that the departure of dentists' couple is, of course, possible thanks to the use of new opportunity structures by opening the British labor market, but, at the same time, as Róża's narrative shows, the departure is forced by the post-transformation situation of this occupational group, when professional activity was not combined with ensuring an appropriate economic status and, to put it bluntly, it did not give the possibility to satisfy economic needs defined as basic ones. ${ }^{11}$

Having four children, Róża was unemployed and her husband had only odd jobs working as a builder, a carpenter, or a postman. However, she quickly managed to find a job in a mushroom farm. It was the only company offering any jobs in the region. Her baby boy was just one month old. She says: "It was some employment without agreement, although perhaps I was hired part-time or something like that," what suggests that she worked without any contract and insurance or she was hired for a fixed-term contract just part-time and worked more than full time, so the biggest part of her work was done as illegal employment, thus not reported, enabling to avoid security costs. It was exhaustive work, sometimes lasting 12 hours, requiring flexibility when growing mushrooms had

${ }^{11}$ The common-sense thinking about educated people and especially from the field of medical work presents this group as tioned project (see: Waniek 2016), as well as in other research contexts show (Kaźmierska, Piotrowski, and Waniek 2012), the transformation, especially at the turn of the 1990s and the first
trats half of the 2000 s (i.e., when Róża works in a dentist's office), was for many professional groups an experience related to the loss of economic status or job at all. to be picked up on time. However, this time she could leave her baby because her mother had been already retired and could take care of her grandson, what was a real relief for Róża. She worked there for one year, and being falsely accused of saying bad words about the boss, she got irritated and dropped the job immediately.

At the same time she got the internship at school as a cleaner. After a month, when a new opportunity appeared, Róża took a one month leave and she went to Norway for a month, where she earned some money to invest in agritourism-she could buy a piece of land nearby her house. This part of her story is not clear enough. It is difficult to understand if she got an internship still working in a mushroom company. When she quit the mushroom farm, she was unemployed for just a week.

After a week Róża got a call from the library master. One of the librarians went on maternity leave and Róża was asked to replace her, starting the next day. She was expected to work only for the time of maternity leave, but because the librarian extended the leave, she had worked in the library for more than 2 years from 2007 up to the beginning of 2010. Róża developed different social activities in the library treating it also as the culture and leisure center for the local community. During this time she got a bachelor degree (two years of postsecondary librarian education were accepted as part of bachelor studies) and she wrote a Master thesis, getting her M.A. This extramural studies at the University of Warsaw gave her the opportunity to meet people from different parts of Poland working in institutions of culture. The network of colleagues she had built appeared to be very fruitful in the coming future.

In 2010, just after finishing working in the community library, she was employed in the school library for a year as the substitute because a woman who worked in the library took a one year leave. Róża got this work being recognized as an active person when she successfully tried to introduce scouting in the school. It was her own initiative. Being fascinated with the idea of European scouting (thanks to a girl scout met on a train during her travel to Warsaw University), she proposed the school master organizing scouting. The scenario from the past two years was repeated: library became a lively cultural center for the whole school. Róża was very respected and appreciated by the school master, yet she had to leave after a year in January 2011, as the person she was substituting came back to work.

On the last day of her work in the school library, she got an email that she won the project for establishing agritourism. She registered her business, built the house, and had her first tourists. According to the rules, for the first year, she had health and pension insurance paid by the state. After a year she deregistered the company. It was September 2011, and she was jobless again. She got just two paid hours a week at school to work with scouts.

As we could see up to this time Róża had completed her education, got experience in running her own business, learned how to apply for a job; thus, she sent lots of applications with her professional curriculum vitae to different places. In the meantime, she got an offer to substitute a librarian in the neighboring town. The offer was for a year, and she obviously accepted it. But, on the same day, Róża got a phone call from the mayor (who read her $\mathrm{CV}$ ) with an offer of a permanent job as a director of the newly built Culture Center. At the beginning she was hesitant as she had no experience in managing human resources, but after having discussed the issue with her family, she accepted the job and was appointed to the position of the director on the 1st of January 2012. Since then Róża has been working successfully in the Culture Center. She had to organize work, got all administration documents for the new institution, and develop its activity. This was the time when she used the network of relations built during her studies in Warsaw.

Róża has been recognized as a very good animator and manager. She is respected in her community, awarded for her work. The Center is a very lively place focused on social and cultural needs of the local community members, promoting folk and higher culture. Róża is also personally involved in many social activities; she often acts in the field of social care and charity as she finds her local social welfare center as not effective enough. Up to now she also makes floral decorations and sells them. She is no longer desperate for money, but she simply likes it.

Of course, Róża's life history can be filled with many other details connected with her family relationships, her husband's professional career, short description of her children's biographies, but I do not have the space to develop these topics. To sum up the presented characteristic, we can say that so far Róża, being 44, has been active on the labor 
market for 25 years, she developed her education by achieving an MA degree, and she is permanently taking part in courses, training, and workshops, some of them she organizes herself in the Culture Center. Her professional CV is very rich: she worked in the healthcare system (dentist assistant), as an unskilled worker (cleaner, mushroom picker, florist in Norway), as a librarian and culture animator (in a public library and at school also in school day rooms), she runs her own private business and developed the idea of agritourism, she is the director of the Culture Center.

If we analyze these facts of her biography in the context of social circumstances and milieu, we should consider that she is the inhabitant of a respectively small rural community where agriculture is the main source of living. The majority of inhabitants have their own small farms and they mainly grow fruits or vegetables. Thus, although in, for example, 2004, according to the statistics, the unemployment rate of $13 \%$ was lower in comparison with the whole region (about 18\%), at the same time the figures do not reflect the real social problem of unemployment when the majority of households having the status of farms were not able to maintain just from farming. Róża's story about searching for work and the status of jobs she got shows that it was very difficult to get a stable position and most of her jobs had the status of fixed-term contracts of employment, renewed many times instead of being replaced by a permanent contract. ${ }^{12}$ It is enough to say that Róża ${ }_{12}$ In Polish language, they started to be called junk contracts 2016 the employer was not obliged to pay pension funds for fixed-term contracts. Reducing costs of work had been treated as one of the strategies to lower unemployment, but from the has worked for 10 years without a permanent contract of employment in the dentist office, and she probably did not have any contract in the mushroom farm. Also, her husband was in the same situation. From this perspective, we can say that, for the main part of her work time, she was in a precarious situation, also including the jobs she did substituting librarians.

At the same time, when we look at Róża's professional curriculum vitae and the strategies she undertook to get out of trouble, we can describe her career using the rich vocabulary of contemporary neoliberal language. We can characterize Róża as: a person who actively searches for a job, who is flexible and ready to face difficulties even if she must work in underqualified positions, she permanently develops her skills, knowledge, and competences, is a very good example of life-long education, she is very creative and has the ability to animate the environment, she finds solutions and never gives up she has a master plan for her life, she is open and not only easily develops relationships and networks, but she also knows how to use them in the future, she is very efficient in using opportunity structures like different state and European funding, workshops, projects, she is very flexible and has the ability to adjust to certain circumstances, she is a real leade in her community, deeply engaged in its life, she develops civil society organizations.

To conclude, she can be a very good example of a person who successfully dealt with the changes,

perspective of the employee, it was a precarious situation generating neither stable prospects for the future nor pension or even health insurance. a beneficiary who can be put as a positive example, or even a perfect model to follow. Here, we could finish our description with the conclusion that, even in difficult life circumstances (early pregnancy), fix-term/no contracts, precarious situations, and difficult labor markets, Róża could manage thanks to all the enumerated virtues of her character and she could be qualified as not only the winner of transformation time, but also a beneficiary of EU opportunity structures. I do not claim that it would be a false image of her biography. Yet, we should also look at her life story-the way she tells her life, the language she uses to describe and interpret her life experiences.

\section{Róża's Life Story}

Having in mind the described chronology of Róża's biographical experiences, I will show now how the narrator presents them in her story. Again, I will focus mainly on her professional career. Thus, I will present these excerpts of her main narrative part related to turning points in her activity on the labor market. ${ }^{13}$ As I mentioned, I must, to some extent, come back to some already presented episodes, which can arouse a feeling of repetition, but I would like to show how the same episode is interpreted by the narrator. In such a way, we may say that in the life history section, I presented the etic perspective-reconstructed Róża's life, whereas now, by explaining the contexts of her experiences and the meaning she gives them, I will try to present the emic perspective.

${ }^{13}$ All the fragments come from the first main part of the narrative interview when Róża spontaneously talks about her life without any interviewer's questions.
Her first job in the dentist office lasted for 10 years. Róża started it being 20 years old, yet with the experience of motherhood. The language she uses to describe her boss resembles a mother-daughter relationship.

I had a wonderful woman doctor, who claimed I didn't need any experience, she would explain everything to me. I needed to take a few courses and they wanted to hire a dentist assistant...My doctor was wonderful, she was only six years older than me. Incredible, she has just left for England, we're still in touch. We write letters, she always visits me when she comes here, she simply showed me a model of a boss. She has this personality, I never felt stressed when going to work. She was always clear, direct. When I came to work the first day, she explained everything to me. And later she never double checked me, never. Be it sanitary inspection, control, or something else, I took everything on my shoulders. And she knew she could simply trust me. That's why it was so encouraging, I simply knew that I do well and the control of sanitary inspection was OK.

When describing the attitude towards her boss, Róża is focused on personal, almost family ties, she distances from the language of professional, institutional relationships typical for a work environment. It is not the language used by persons focused on their professional career and development. Róża tries to be a devoted worker and the relation is built on mutual trust and not on professional procedures. Referring to the classical typology by Ferdinand Tönnies (1988), we may say that Róża frames her work in Gemeinschaft, what can be observed based 
on spontaneous arousal of emotions and expressions of sentiment.

We may assume that during the first ten years of her work in the dentist's office Róża gained experience and maturity. In the meantime, she had three more children, she completed post-secondary librarian college. At the same time, it should be noticed that librarianship was not her own biographical plan. It was undertaken due to two reasons: firstly, her mother insisted that Róża continue her education after breaking her plans due to the first early pregnancy; secondly, she followed her friend because she did not want to study alone. Again, her agency is framed not by neoliberal standards of individual, planned, independent biography, but by well-known and tested Gemeinschaft patterns-family ties and friendship.

We can also say that although Róża undertook different initiatives during her first ten years of work (besides those aforementioned she took part in training and applied for funding to start a private business), first of all, she appreciated the stable position of her work and particular family relationship with Mrs. Doctor. She never complains in the interview that for ten years she did not have a regular permanent contract, it was renewed each year as each year the dentist was receiving a new contract and funding to run the dentist office at school. So, although it was a precarious situation and probably not a well-paid job, its guarantee was defined not in frames of institutional management, but "face to face" trust relationship.
The next few years, which can be described as difficult yet a successful development of Róża's professional career, are presented by the narrator in a totally different mood. We can point here to at least three threads: the risk of trajectory of suffering; finding the solution in local community trust-relations, as well as family ties; looking for external help or intervention. All these three threads merge, but they should be analytically distinguished.

From the life history description we can imagine that, although Róża lost or ended her jobs a few times, she could immediately find a new one. This may create the illusion that it was not only her openness and flexibility, but also open possibilities on the local labor market that enabled her to find a new job. However, when we see how Róża describes these moments in her narrative, it appears that they were connected with the experience of trajectory of suffering. ${ }^{14}$ Its strong potential could be stopped by getting new jobs, but its danger was experienced very deeply. Below I present a part of her narrative divided into three fragments in order to show how she develops her story and what kind of interpretation stands behind it.

When Róża learns that she could no longer work in the dentist's office, she says:

So, Janek was born and I intended to come back to work. I am about to go and tell the doctor I want to come back in a month, and my doctor let me know when an individual is suppressed by circumstances that tak
control of one's life course (see: Riemann and Schütze 1991). that, unfortunately, I can't return to work. I had simply tears in my eyes, I don't know what's going on, how did I deserve it. ${ }^{15}$ Mrs. Doctor says nothing has really happened, she says they got a contract in England. Her husband was a dentist and says there are just way better prospects there, you know. They packed up and left for England, even more understandable that they had one child and better money there. I was in despair. I was left stranded with four children, without a job. My husband took odd jobs, he made coffins, he's a carpenter and a builder err he was working as a postman too. Simply all professions, he took all jobs, but every job was temporary. And, I say, what will I do, for me it was a total disaster.

Róża wanted to continue her biographical plan to work for "the good master," but when she was informed that her contract could not be prolonged, the first interpretation that came to her mind was self-accusation about having done something wrong. It is a very interesting language construction-“how did I deserve [to be fired]". It shows not only a very personal relationship with her boss, but also the interpretation of her situation in terms of liegemen-master relation. This language of dependence is built on the bases of trust and ego-centric relationship, and it cannot be recognized as modern work relations. From other parts of this quotation we can learn about the social frame of the situation. Róża appears to be privileged having a stable position (although, objectively, each time it was just a one year contract with the promise of renewal), whereas her husband's situation is very unstable. As I wrote earlier, this part of Poland was endangered by high

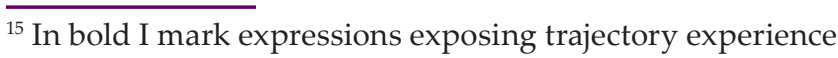

unemployment and official figures did not illustrate the real phenomenon as those who had small properties, like 1 hectare, were qualified as farmers (and were not included in the statistics of the labor market), although they had no chance to make a living from farming on such a small piece of land. Róża was in a similar situation, although her work at the dentist office, framed by a good relationship with her master doctor, gave her the illusion of stability. In fact, it was also a precarious situation. On the other hand, in comparison with her husband, she described it as safe and stable. In Róża's story, the year 2005 was the first time she felt insecure and had to fight for the solutions to maintain the family. The words like "total despair," "disaster," "tears in my eyes" express the experience that the potential of trajectory of suffering had just been opened. As we could see when analyzing further parts of her story, she reports her experiences in the mode of building-up the trajectory potential (Riemann and Schütze 1991:349). This potential in Róża's story approaches and withdraws a few times. She continues her narration:

But, when Janek was one month old at the most and there's a mushroom farm nearby, so I went and asked if they would hire me. And they hired me for a trial week. As I was working fast, they hired me at once. It was some employment without agreement, although, perhaps, I was hired part-time or something like that. And I was working on that mushroom farm for a year. Sometimes my heart ached because we were supposed to work for eight hours, let's say, and there were lots of mushrooms and we could come back home after twelve hours. The child was small, my breasts hurt, this job was a painful experience. (.) ‘Cause they 
wouldn't let us go home for a while, but I had to express the milk, all I earned, my mum here was taking care of Janek 'cause she had retired already. So, thank God, I had a safe haven of sorts at home 'cause mum would look after the children. So, I, you know, needed to earn for milk for children, right.

This fragment goes just after the previous quotation. We may say that, actually, the trajectory did not develop or even start. But, if we analyze the language she uses and the situation she is put in, we can easily recognize the trajectory potential. We see that Róża reacted immediately, she revised her plans and found a new job. Probably, if she could have continued her work at the dentist office, she would not have come back to work just after a month from the delivery. The new unstable situation made her react as soon as possible, what can be interpreted as an attempt to overcome the trajectory. Again, this situation can be interpreted from two perspectives: it can be treated as Róża's ability to react and act in difficulties. She can be presented as a creative person with agency, having the ability to deal with difficult situations and adapting to the needs of the labor market. This interpretation stops at the level of facts and acts, but, if we consider how Róża presents her new work and what she exposes, the image is more complicated. First of all, as already noticed, we can assume that Róża had not planned such a quick return to work. Yet, when she lost her stable position, she was in despair about the possibility of staying jobless and compulsorily looked for a new job. Secondly, compared to a dental assistant, the new job was not a social advancement-on the contrary, it was a degradation. Róża started working as an unskilled laborer in, as we know from the con- textual knowledge, the only workplace offering any kind of employment. Thus, both the decision to take up this job quickly and its nature show that Róża saw her situation as extremely difficult. Finding this job only to a certain extent made it possible to control the trajectory risk, because, as the description shows, the work itself was very hard, entailed the necessity of working overtime, and the lack of stability of employment. At this time, Róża was balancing between an "intentional and conditional state of mind" (Riemann and Schütze 1991:349).

Thus, taking into account the analysis of the narrative, it is difficult to expose the agency and subjectivity-Róża had to adapt to difficult external circumstances, which put her in the position of a victim in this respect. The only favorable context turns out to be her family capital-her mother/grandmother retired and could take care of Róża's children. ${ }^{16}$

\section{She continues:}

And I was working for a year. Then, I was accused of verbally abusing my boss. Somebody did it and they heard it and they said the voice was similar to mine. And they accused me that it was probably my voice, it was me. My workmates say that Róża doesn't swear, all right, but the voice sounded similar. So, it was probably the right stimulus at the right time. So, I took off the apron, took off those rubber boots which one wears while picking mushrooms and said: "If Ms. boss thinks that I did it, so I'd like

${ }^{16}$ It is worth noting here, by the way, that we are dealing with a reproduction of family relations models-Róża herself was raised, to a large extent, by her grandmother, because her mother worked. to thank you for this job and quit." They apologized to me later, I say, pay me out my wage, please, and that's it. I came back home, was in despair for a week and then suddenly the library boss rings me and says that my workmate left for maternity leave and she needs someone. I say: "When? I graduated from librarianship study. When? From tomorrow." I remember I was vacuum cleaning then, I dropped it and couldn't wait for tomorrow. That the madam from the library rang me at home is quite amazing, told me to come to work. I say, beloved God, it must be some, I don't know, God's intervention. And I went to that work.

The above fragment confirms the earlier description-the work on the mushroom farm was very hard and, what is more important for Róża, not based on the relationship of trust. All this causes the impulse-driven quitting the job-in a literal and metaphorical sense-she took off the apron and left. Taking into account Róża's care for the protection of her family, at the same time we can imagine that working on the mushroom farm must have been beyond her physical and mental strength. She decided to take a desperate step, which, again, brought the potential of the trajectory closer and caused a feeling of despair. Fortunately, it only lasted for a week. A picturesque and detailed reconstruction of the scene of answering the phone with a job offer shows how important this event was. At this particular moment, in Róża's life, the trajectory potential was stopped once again. It appeared also to be a turning point in the perspective of the further biography, when Róża started to develop her professional activity, which will eventually lead her to the moment when she is telling her life story.
In this fragment, appear two more threads to be considered. First of all, we find here a reference to transcendence. Here, and in the following passages, Róża does not speak about the coincidence or agency in relation to her own competence, but of God's intervention. As it turns out from all the self-presentation in the interview, these are not only rhetorical phrases, but a sincere conviction resulting from the narrator's religiosity. Róża is a strong believer and she interprets her life within the frame of her faith and God's agency. I will return to this thread again. Secondly, an important element determining the chances of Róża on the labor market is the mutual relations between local milieu and the labor market. Róża replaces her colleague at work. From a further fragment of the narrative we learn that this position was originally intended for the cousin of the mayor. However, the cousin was not interested enough in it, nor did she have any qualifications. Demonstrating her high competence, Róża soon gained the recognition of the mayor and was employed legally. ${ }^{1}$

As we know from Róża's life history, she managed to work as a replacement for more than two years. Then she got the opportunity to work in the school library as a replacement. Here comes the next

${ }^{17}$ For a while the library master was informing the mayor that Róża worked as a volunteer, although she was somehow paid for her work. In this short description of relationships, we see that positions in the local milieu are delegated through the mixture of networks and competences. Between the lines, Róża sometimes suggests that in such a local community mutual relations and influences are important and tensions may arise. It should be stressed, however, that from the perspective of her In other words, her narrative is not devoted to the character of social relationships typical for or specific to the local community. Róża's story is devoted to her biographical experiences inscribed in the reality of this community. 
fragment when she describes her situation after a year of work as a school librarian:

Five years ago, in 2009, that's right, it was six years ago already. The headmaster came up himself and says: "Róża, you should stay here." However, unfortunately, my agreement was only for a year, my colleague returned. And I simply, I was crying, the deputy headmistress was crying, 'cause I just found myself there. But, unfortunately, it's a normal course of events, I had to leave. (.) So, what then, I say, I remember I finished on the tenth err my agreement came to an end on the tenth of January, the agreement was signed and it was simply a great despair on the last day of work. And I'm sitting in the library in front of a computer, it's over, I need to leave. And I open my email box and I read I won a project, forty thousand for an agritourism business. And I simply really don't know if there you are God and protecting me. So, there was just no break. My agreement came to an end, I set up my company right away, agritourism business, it was obligatory to lead this for a year. So, I got forty thousand, we built a house/ it wasn't enough to build, but at least enough for the roof and furniture, so I was leading that activity for a year. I had to be self-employed, it's closed now, but I'd like to do it in the future. (.) So, social security premiums were paid for another year, I had no break from work, 'cause I finished work at school I started my business activity.

In this fragment, the trajectory potential is hidden-Róża does not have to wait for another chance as she smoothly moves from one job to another. However, there are a few issues worth considering. First of all, the trajectory threat, al- though eliminated, does exist. The narrator again uses the same language: "It was simply a great despair on the last day of work." Secondly, the human relationship is again in the foreground. Róża's story suggests that she was a more active worker, better at fulfilling her tasks than the person she replaced. The logic of the neoliberal labor market would suggest the dismissal of the previous librarian and the continuation of cooperation with Róża. However, this is not her post, it belongs to a person on a one-year leave. Relationships of work, trust, and responsibility are more important than the competence and creativity of an individual. Thirdly, once again, there is a reference to God's intervention. Several attempts to apply for a small business grant had failed-the fact that Róża received it at the moment she desperately needed support could not be described by her as just a fortunate coincidence.

Let me quote another fragment of the story in which Róża refers to the last turning point in her professional biography. After running her business for one year, when security premiums were paid by the state, she closed the company because she could not afford paying security premiums by herself.

And what, another year passed by. And again, they stopped paying social security premiums, closed my company, and what, nothing again, and what. (.) I was in church in September, yes. Children were going, my scouts, all were going to the opening of the school year, the mass on the opening of the school year, all are going. I remember clearly I was standing with tears in my eyes near the organs, every- body is going to work, and I put so much heart into this profession and I don't have a job again. I remember I was the last one to go down the stairs in church and nothing. And again with those scouts, as I had, I was meeting them once a week, and, but the headmaster says go to the mayor, he should assign you some hours. And the mayor assigned me two hours at school, total madness, two hours a week isn't much. Anyway, I was happy even with it, 'cause I was doing whatever I could with scout. And my headmaster says: "Listen, in D. [small village in Southeast Poland] some librarian is going on maternity leave again."

Further on, Róża reconstructs in great detail the conversation with the library director and with the mayor, who offers her the job of a director of the culture center. Róża accepts it after two days of reflection-as she says, she had no experience in human resources management. The family convinced her that this was an opportunity for her and for the whole family-for the first time it was possible to stabilize the professional career and life situation of the whole family. From that time she has taken up the post until today-she has been working as the director of the cultural center. This fragment (if we take it as a whole, including also its not quoted part) is rich in detailed descriptions of conversations and interactive scenes, what indicates the significance of the sequence of events and their experience in the life of the narrator. But, let me go back to the quoted excerpt. Here, too, we are dealing with a meticulous reconstruction of the scene, the consequence of which is not a sudden turn of events (as it happened in the described "vacuuming" scene when Róża answered the phone with a job offer), but its aim is to recreate the emotions accompanying the narrator. This is another moment of suffering connected with inability to take up the work that the narrator has all the competences to perform. Not without significance for the whole narrative is the fact that Róża invokes a scene in a church, during a mass-again, we have here a reference to transcendence and, although Róża does not say it directly at this point, the interpretative framework that she gives to her whole story requires us to interpret this fragment as another call for God's intervention.

\section{What Can We Learn from This Single} Case Study?

In Róża's life story, it is difficult to look for a planned, rational project of her life. The main theme of her narrative, expressed literally in the coda, is the conviction, "so I think it should work out somehow." It is based on a deep religiousness and a sincere trust in people. Using William James' (2017) statement, she has the will to believe both in terms of religious convictions and one's ability to accomplish tasks that require confidence. The key to understanding her biographical experiences is trust at different levels: in God, people, the local community.

The conviction of the presence of God in the form of his intervention in difficult situations is the consequence of Róża's deep and sincere religiousness. It is related to belonging to a local community (this part of Poland is characterized by a high degree of religiousness) and is, at the same time, a living religion, practiced from 
childhood through various activities such as participation in the school choirs, leading prayer groups, youth camps organized by the priest, pilgrimages to Czestochowa. Róża does not emanate her religiousness in an interview, but includes it naturally in the course of events and experiences, considering it as something normal and obvious. She also blurs the boundaries between the sacred and the profane, which overlaps with the division into the private and public spheres. Her description of relations at work is very significant.

I mean, I'm extremely pleased with my work. I manage a nice crew, I hired my employees myself. It wasn't like I came here and started managing a group, which was created. But, I just selected my team members, some of them had an internship here before, some sent applications directly to me. And I make a very nice group at work. We also joined a foundation Orszak Trzech Króli. ${ }^{18}$ I have organized a parade in $Z$. (small country town in Southeast Poland) twice and they also have such err sort of challenged everyone who belongs, that it was possible to join them and pray the Angelus at noon. So, we always set our alarm clocks in the office, everyone at work knows they go on the carpet in the director's office at noon and pray the Angelus. So, it's very inspiring for us/ and no one from outside knows about our secret. They don't even know about it, but it's just our, our professional secret. We meet there in my office for some five minutes, pray the Angelus and disperse. I guess that we'll handle it somehow.
As we can see, Róża smoothly moves from the context of a public institution to the sphere of religious activities and vice versa. In her story, they are inseparable, whereas the strict division of these two spheres is characteristic to modern society. Very interesting here are rhetorical phrases usually used in the context of institutional relations in the world of work, for example, "they go on the carpet in the director's office"-this term is used with a distance to the commonly understood "to be called on the carpet," which usually means difficult confrontation with the boss, where the relations of power are revealed. On the other hand, the term "our professional secret," which usually describes the accumulation of professional competences here, is transferred to the sphere of non-professional (but highly bond-forming) activities.

Trust in people is revealed in various dimensions of biographical experiences, from the described relationship between Róża and her grandmother, then with Mrs. Doctor, through building a network of relations in youth work or with employees of cultural institutions scattered all over Poland, with whom Róża studied in Warsaw and now uses these contacts in her work. In each of these dimensions, she is a meaning resource; how to deal with relationships and trust relation shapes her attitude to other people, thus her experience is both formed and based on the tradition of doing social relations. This trust in people is supported by and at the same time builds the trust of the local community. In this context, Róża turned out to be a master of social work in terms of symbolic interactionism. ${ }^{19}$ All that she does is not supported by some kind of her individual plan-the power of doing social innovation comes from culture and community. At the same time, she has the ability to construct new opportunity structures for the local community.

Although Róża has always been reconciled with her life, trusting that "somehow it should be worked out" has allowed her to take on new challenges that are not formulated in the biographical action scheme. They just happen, but, as a result, lead her to a metamorphosis ${ }^{20}$-a radical positive change in her life. She experiences a social upgrade in an objective and subjective sense: she has a prestigious position in her local community and she can fulfill her dream of working with people:

It was my dream to be a teacher, to start with, I was the youngest, I mean, in this part of R. (small village in Southeast Poland) to lead kids to May prayers, I was always gathering a group for church services and I was sort of a leader. (.) So, a spirit of leadership and guardianship was always running in my blood, therefore I wanted to be a teacher. And I was thinking a lot about Polish philology.

She has not become a teacher, but she achieved much more gaining the ability of being a "fulltime" leader. What is more interesting, the metamorpho-

In the narrative Róża gives many examples of her activity in the field of social work and charity. They are undertaken with family members and local inhabitants. She does it apart from her professional activity.

${ }^{20}$ Metamorphosis is the process structure of an unexpected, positive change in one's life which makes it possible to discover new possibilities that may lead to a radical change of one's life (Schütze 2008). sis mode becomes in a way a constant pattern of her action. We can even describe it as a metamorphosis potential ${ }^{21}$ which, in a way, eliminates the trajectory potential. It is undertaken in the fashion of happening events that she meets on her way, not in the mode of expectations and biographical plans. Such an attitude is possible because her main biographical resource is a trust relationship.

So, we are dealing with a life story rooted in milieu and community oriented, but, at the same time, strongly individualized, characterized by resourcefulness. I refer here to the analytical dimensions developed in the research Biography and National Identity, where rootedness in milieu is described as "placing one's own biographical and interbiographical processes (e.g., family processes) in the local microenvironmental plan" (Czyżewski 1997:46). In the case of Róża, although her story shows some, so to speak, universal features of a social activist and leader, it is also clear that they gain biographical significance in the local milieu. It is not a question of saying that Róża would not be able to develop elsewhere, but of exposing the symbiosis of her biographical experiences and the process of giving them meaning by including them in the local community.

In the mentioned research, resourcefulness was defined as "coping with the requirements of a micro-social situation characterized by dominan macro-historical conditions" (Czyżewski 1997:46) and diagnosed as one of the characteristics of

"I would like to thank the reviewer of my article, whose name I do not know, for suggesting the idea of a potential metamorphosis and cultural resilience. 
the Polish society's cultural resources. This is very visible in Róża's narrative. The belief that "it should work out somehow" is connected with active searching for solutions and coping with crisis situations. Researchers in the commented project enumerated two dimensions of resourcefulness: as dealing with trajectories of suffering and as a feature of an autonomous action plan (Czyżewski 1997). Róża's narrative shows that resourcefulness can also be associated with a metamorphosis leading to a significant, positive change in life. Undoubtedly, the presented case is an example of launching the culturally rooted resources of the symbolic universe characteristic of Polish society. We can also notice that an individual usually tries to control trajectory potential by introducing a biographical action scheme. In Róża's case, it is rather metamorphosis due to her ability to attach readiness to accept appearing solutions.

One can also try to relate Róża's narrative to another notion of resilience, recently used in social sciences. It is a concept quite widely used in psychology, educational sciences (where it has been successfully applied to both children and adults capable of overcoming unfavorable life conditions), and in community/ecological systems studies, where it has been used in research on natural and man-made disasters. Such studies show that resilience is at the same time the process of, capacity for, and outcome of, successful adaptation despite challenging or threatening circumstances (Masten, Best, and Garmezy 1990; Williams 2008; Endress 2015). Many models and theories of resilience, which so far have been developed in the social sciences, tend to refer to resilience, to put it generally, in terms of the capacity of an individual, a community, or an ecological system to return to its original shape after cessation of, or overcoming, stressful and disturbing circumstances. In such a context, resilience is defined as the ability of an individual, a family, a community, a region, or a country to withstand, adapt, and recover from stresses and shocks caused by crises and disasters. The role of the community and local community, in particular, could be vital for surviving a crisis (Chaskin 2008). The narratives of resilience appear as normative constructions of an understanding of "good coping," like particular expectations of community members to be able to adapt to the situation of crisis and, which in an opposite case of inability to adapt, might lead to stigmatization of individuals and whole communities (Harrison 2012).

This concept was somehow reintroduced into the scientific discourse during the last crisis in 2008 . The crisis in the sphere of finance was quickly transferred into social problems, for example, increased unemployment, especially among young people, loss of trust in public institutions, et cetera. As I noticed, resilience aims at returning to the state before the crisis. It can be said that Róża's activity may be characterized by resilience, she has the ability to find solutions and act quickly in crisis situations in order to return to the previous state. Yet, it is a specific kind of resilience that may be called cultural resilience. Róża successfully uses "old" values in the "new" world. Whenever she finds herself in a new situation, she adapts to new opportunities, but in traditional frames. So we can notice a paradox here. The transformation process assumed a change without the intention of returning to the previous state. Meanwhile, Róża implements transformational changes through resourcefulness, but also through resilience. In fact, the point is that nothing should change in the field of the construction of social life and the traditional hierarchy of values. In a sense, it is about the return/maintenance of the status quo. ${ }^{22}$

Thus, Róża's case exemplifies the main paradox-the merging of modernity and traditional society values. She uses both in order to give meaning to her biographical experiences, as well as be an active actor in the process of local community development. She is an example of a leader who moves effectively in the contemporary reality of a modernized society and metamorphosis potential in her biography can be well attached to the expectation of a neoliberal system where the individual is "an 'entrepreneur of himself,' who constitutes capital for him-/herself and who becomes a producer of him-/herself" (Czyżewski 2009:91). But, we can hardly find such auto presentation in Róża's narrative. To the contrary, what we find is that the interpretation of her life story requires references to a language that characterizes society with traditional values. Thus, in the presented case, the transformational changes do not follow the model of a complete modernization of social life if we understand them as a unidirectional process with clearly identifiable characteristics (Joas 2016). The example of such a perspective can be seen in Giza-Poleszczuk's critical statement. "Religiousness of Poles is presented [in media discourse] as the

${ }^{22}$ It is not, of course, about the issues of systemic change in the political dimension and the dream to come back to the political system before 1989. Such resentments are also part of some
kind of nostalgic thinking, but it is a completely different problem that I do not discuss in this paper. main barrier blocking us from modernity. Hence, the great enthusiasm for all the statistics showing the progress of our secularization. And yet religion is not a slavery that hinders progress, but an ethical attitude that is supposed to be a testimony to such values as love of neighbor, kindness, or compassion. Religion is therefore an essential 'social glue' that allows people to be generous to themselves. Without such generosity, all human relationships are reduced to a commercial system. Society then ceases to exist. That is why the theory of modernization applied here, in which the traditional society with its values is a barrier to modernity, was absurd" (Giza-Poleszczuk 2018).

The quote describes the mechanism of creating the mainstream vision of social change-we are able to build a common world with others, only then we exclude the Other-strangers to such an extent that we have the right to despise them. The case of Róża is problematic for such a perspective: her activity in the professional and social sphere is possible to be carried out successfully since it is based on traditional values, and the local community will develop on the basis of them and not in contrast to them, for example, in relation to a neoliberal social project. Thus, the conservative and traditional Róża, cultivating family, religious, and community values has at the same time become a carrier of the values of civil society and makes effective use of modern opportunity structures. What is more, these features become a social glue that integrates and does not exclude in the local community. This conclusion can be valid not only for those in favor of modernization who consider that secularization should be a condition of modernization, but also for the orthodox 
rhetoric of the Church. Especially that the symbolism of oppression, sacrifice, and survival remains an important resource for building the sense of superiority and inferiority (Piotrowski 2006).

Thus, the analysis of this case shows the ineffectiveness of schematic rationalizations, questions the unidirectionality of the social change process (in the social and cultural dimension), shows to what extent the effects of transformation on the dimension of macro-social level can influence social change in the local and individual dimension.

\section{Conclusions}

One may say that the main part of the article has nothing in common with the winner/loser categorization. It was exactly my argumentation in this text. The presented analysis can be concluded from different perspectives. I would like to pay attention to two of them: the methodological and interpretative ones. In the analytical context, they merge. I intended to show what kind of conclusions can be derived from the material when it is analyzed at the level of facts presented in the life history and at the level of the narrator's interpretations presented in the life story. We can apply here to the concept of the subject, distinguishing between "biography as a theme" and "biography as a means." In the first case, biography is treated as an issue in itself, the researcher's interest is directed at the structure (narrative/biography) and expressed in the question how is the narrative constructed, how do the interactive conditions of its production shape the story, how does the biographical reconstruction of the life course take place, et cetera. In the case of "biogra- phy as a means," the question of what comes to the fore. What is told enables gathering biographical in formation to answer typical sociological questions (e.g., social structure, strategies on the labor market) (Helling 1990:16). The life story corresponds with "biography as a theme," whereas the life history with "biography as a means." Very often the second approach is supported by the etic perspective, whose aim is to describe an individual's experiences with the help of categories not grounded in the empirical material, but imposed by the researcher. As I intended to show by the analyzed case, Róża's life history could be a very good empirical material to illustrate a successful development of competences that lead her to the position of the winner. We could also say that Róża has become a beneficiary of social change when she effectively uses opportunity structures, for example, state and European funding to develop various social activities, on the one hand, and to continue self-education and developing of private business, on the other hand. Of course, we cannot say that it is a false interpretation-Róża can be considered as an example of a successful person and her achievements result from her hard work and determination to achieve goals (to describe her biography in neoliberal language). But, finishing the analysis at this level, we miss the most crucial items of her biographical experiences. They could be studied on the level of her life story that enables seeing the emic perspective and the way an individual gives meaning to his/her experiences.

It should be stressed that life history and life story are not contradictory stories-to the contrary. "Being truthful to our experiences, we cannot invent the life-story as pure fiction, but depend on our life history...What I have been through, my life as I lived it, the communication with my fellow humans and its relevance...all goes into my life story" (Fisher-Rosenthal 2000:116). So, we should be very careful when going from the level of life history to life story and vice versa. As I noticed in the analyzed case, we could see that, when at the level of life history, the categories of winners-losers would fit with Róża's image of life based on presented facts and she could be smoothly presented as the winner. Moreover, she could be a model example of a self-made woman, developing her skills and not surrendering to difficulties. Whereas if we consider her life story, it appears that her success is not the result of activities that could be analyzed by a winners-losers dichotomy and all the described normative categorizations, but rather by motives and relations belonging to completely different social resources.

It does not mean that winners-losers categorization is totally out of context. For sure, it describes, to some extent, opportunity structures that put some people in advantageous positions and some others not. Yet, it is symptomatic that in our collection of 90 interviews only one person used this category as the self-description. ${ }^{23}$

Narrator: And my old folks, who had been working for several decades err in the former epoch didn't get absolutely anything, apart from the fact that they get some pensions, which enable them to get by err better or worse. Therefore, from the perspective of those,

${ }^{23}$ In the third part of a biographical narrative interview, when the researcher is entitled to pose theoretical questions related to the studied problem, we never asked interviewees about winners/losers categories. those changes which took place, well, I can be perceived as a beneficiary.

Researcher: In scientific jargon, it's called "winners and losers of the transformation."

N: [chuckling] So, I rather belong to the former.

The quotation comes from an interview with a three years older man working in banking in one of the big Polish cities. We can assume, and it can be seen in his life story, that a neoliberal way of thinking and acting is not just the adapted ideological language, but his perspective, especially in the frames of professional career. As I noticed, it is the only example of using this category. Perhaps if we asked our interviewees, “Do you feel a loser or a winner?" some of them would try to attach to one of these categories, what still would not prove that they truly identify with them. Giza-Poleszczuk described this type of reasoning in a very critical way: "We [sociologists] have not anticipated any of the important changes of the last 30 years, because we have lost the ability of a true sociological analysis. True, that is, holistic, with a broader context, and not just using Western cliché. The mechanism of 'public opinion washing' is also extremely harmful. It is that we ourselves create public discourse by imposing certain labels in order to convince people that this is what they think. We analyzed this with a group of colleagues in 2009, when we celebrated the 20th anniversary of the Round Table. In the media, one side was talking about a 'social contract,' the other about a 'collusion of elites.' In the midst of this media storm, the CBOS asked the citizens a question: 'In your opinion, was the Round Table (a) a social contract; (b) a collusion of elites?" This is what I call the 'opinion washing' mechanism. First, we create a narrative, then we 
publicize it, and then we tell people that these are their own opinions" (Giza-Poleszczuk 2018). I think that the same mechanism has worked in the case of winners/losers categorization as a "created narrative" to be imposed on people's ways of dealing with the social change.

Róża uses neither these categories nor this perspective. To describe her experience we need dif-

\section{References}

Bugaj, Ryszard. 2010. “Społeczne i polityczne uwarunkowania przekształceń w gospodarce polskiej." Pp 13-31 in Po 20 latach. Polska transformacja z perspektywy ekonomicznej, socjologicznej i prawniczej, edited by P. Kozłowski and H. Domański. Warsaw: IFiS PAN.

Chaskin, Robert J. 2008. “Resilience, Community, and Resilient Communities: Conditioning Contexts and Collective Action." Child Care in Practice 14(1):65-74.

Czyżewski, Marek. 1997. “Geneza, kierunki opracowań, wymiary analityczne." Pp. 45-51 in Biografia i tożsamość narodowa, edited by M. Czyżewski, A Piotrowski, and A. Rokuszewska-Pawełek. Lodz: Uniwersytet Łódzki, Katedra Socjologii Kultury.

Czyżewski, Marek. 2009. "Między panoptyzmem a 'rządomyślnością' - uwagi o kulturze naszych czasów." Kultura Wspótczesna 2:83-95.

Endress, Martin. 2015. “The Social Constructedness of Resilience." Social Sciences 4:533-545.

Fisher-Rosenthal, Wolfram. 2000. "Biographical Work and Biographical Structuring in Present-Day Societies." Pp 109-125 in The Turn to Biographical Methods in Social Ccience. Comparative ferent language. Thus, these two different levels of analysis can bring various results and the etic level could perhaps illustrate some social process, but it would be very difficult to understand them from an individual perspective. This could be the reason for the misunderstanding of people's motives and, for example, political choices, but also social phenomena and processes that stand behind them.

Issues and Examples, edited by P. Chamberlayne, J. Bornat, and T. Wengraf. London: Routledge.

Giza-Poleszczuk, Anna. 2018. Jako socjologowie straciliśmy zdolnos prawdziwej analizy [ROZMOWA] z prof. Anna Giza-Poleszczuk rozmawia Krzysztof Mazur. Retrieved October 13, 2019 (https://klubjagiellonski.pl/2018/05/20/giza-poleszczuk-jako-socjologowiestracilismy-zdolnosc-prawdziwej-analizy-rozmowa/).

Giza-Poleszczuk, Anna, Mirosława Marody, and Andrzej Rychard (eds.). 2000. Strategie i systemy. Polacy w obliczu zmiany spotecznej. Warsaw: IFiS PAN.

Golczyńska-Grondas, Agnieszka and Małgorzata Potoczna. 2016. "Z klasy robotniczej do pomocy społecznej. Biograficzne doświadczenia dawnych 'beneficjentów socjalizmu' w postindustrialnym polskim mieście." Przeglad Socjologii Jakościowej 12(2):18-34.

Harrison, Elizabeth. 2012. "Bouncing Back? Recession, Resiience and Everyday Lives." Critical Social Policy 5:1-17.

Helling, Ingeborg. 1990. “Metoda badań biograficznych." Pp. 13-37 in Metoda biograficzna w socjologii, edited by J. Włodarek and M. Ziółkowski. Warsaw, Poznan: PWN.
James, William. 2017. The Will to Believe. New York: Create Space Independent Publishing Platform.

Jarosz, Maria (ed.). 2005. Wygrani i przegrani polskiej transformacji. Warsaw: Oficyna Naukowa.

Joas, Hans. 2016. “Dangerous Nouns of Process: Differentiation, Rationalization, Modernization." Pp. 149-162 in The Art and Science of Sociology: Essays in Honor of Edward A. Tiryakian, edited by R. Robertson and J. Simpson. London: Anthem Press.

Kaźmierska, Kaja, Andrzej Piotrowski, and Katarzyna Waniek. 2011. "Biographical Consequences of Working Abroad in the Context of European Mental Space Construction." Sociological Review 60(1):139-157.

Kochanowicz, Jacek and Mirosława Marody (eds.). 2010. Kultura i gospodarka. Warsaw: Wydawnictwo Naukowe Scholar.

Kozłowski, Paweł and Henryk Domański (eds.). 2010. Po 20 latach. Polska transformacja z perspektywy ekonomicznej, socjologicznej i prawniczej. Warsaw: IFiS PAN.

Król, Andrzej. 2015. Byliśmy głupi. Warsaw: Wydawnictwo Czerwone i Czarne.

Marody, Mirosława (ed.). 2000a. Miedzy rynkiem a etatem. Spoteczne negocjowanie polskiej rzeczywistości. Warsaw: Wydawnictwo Naukowe Scholar.

Marody, Mirosława. 2000b. "Instytucjonalne ramy negocjacji społecznych." Pp. 75-90 in Miedzy rynkiem a etatem. Społeczne negocjowanie polskiej rzeczywistości, edited by M. Marody. Warsaw: Wydawnictwo Naukowe Scholar.

Marody, Mirosława. 2004. “Wstęp." Pp. 9-12 in Zmiana czy stagnacja,? edited by M. Marody. Warsaw: Wydawnictwo Naukowe Scholar.

Masten, Ann, Karin Best, and Norman Garmezy, 1990. “Resience and Development: Contributions from the Study of Children Who Overcome Adversity." Development and Psychopathology 2(4):425-444
Pańków, Włodzimierz. 2010. "Transformacja jako ciąg efektów perwersyjnych i przywracanie społecznej równowagi." $\mathrm{Pp}$. 59-79 in Po 20 latach. Polska transformacja z perspektywy ekonomicznej, socjologicznej i prawniczej, edited by P. Kozłowski and H. Domański. Warsaw: IFiS PAN.

Pike, Kenneth L. 1967. Language in Relation to a Unified Theory of the Structures of Human Behavior. The Hague: Mouton.

Piotrowski, Andrzej. 2006. "Proces kształtowania się tożsamości narodowej w dyskursie potocznym i publicznym." Pp. 327-340 in Obszary tadu i anomii. Konsekwencie i kierunki polskich przemian, edited by A. Miszalska and A. Piotrowski. Lodz: Wydawnictwo UŁ.

Pisz, Zdzisław. 2000. “Doświadczenia społeczne w procesie transformacji systemowej w Polsce w latach dziewięćdziesiątych." Problemy Polityki Spotecznej. Studia i Dyskusje 2:101-122.

Riemann, Gerhard and Fritz Schütze. 1991. “Trajectory as a Basic Theoretical Concept for Analyzing Suffering and Disorderly Social Processes." Pp. 333-358 in Social Organization and Social Process: Essays in Honor of Anselm Strauss, edited by D. Maines. New York: de Gruyter.

Rosenthal, Gabriele. 2004. "Biographical Research." Pp. 48-64 in Qualitative Research Practice, edited by C. Seale et al. London:

Rychard, Andrzej. 2000. "Przedmowa." Pp. 9-12 in Strategi i systemy. Polacy w obliczu zmiany spotecznej, edited by A. Giza-Poleszczuk, M. Marody, and A. Rychard. Warsaw: IFiS PAN.

Sadowski, Zdzisław. 2010. "Sukces transformacji a warunk rozwoju Polski." Pp. $32-43$ in Po 20 latach. Polska transformacja z perspektywy ekonomicznej, socjologicznej i prawniczej, edited by P. Kozłowski and H. Domański. Warsaw: IFiS PAN.

Schütz, Alfred. 1990. Collected Papers II: Studies in Social Theory. The Hague: Martinus Nijhoff.

Schütze, Fritz. 2008. "Biography Analysis on the Empirical Base of Autobiographical Narratives: How to Analyse Autobiographical Narrative Interviews." European Studies on Inequal- 
Kaja Kaźmierska

ities and Social Cohesion 1/2 (part I):153-242, edited by A. Golczyńska-Grondas.

Tarkowska, Elżbieta. 2000. Zrozumieć biednego. O dawnej i obecnej biedzie w Polsce. Warsaw: Wydawnictwo Typografika.

Tönnies, Ferdinand. 1988. Wspólnota istowarzyszenie. Rozprawa o komunizmie i socializmie jako empirycznych formach kultury. Warsaw: PWN.
Waniek, Katarzyna. 2016. “Potencjały bezładu i cierpienia w biografiach młodych kobiet wchodzacych w świat sztuk i medycyny." Przeglad Socjologii Jakościowej 12(2):114-144.

Williams, Robert. 2008. "Resilience and Risk in Children and Young People." Pp. 107-118 in Child and Adolescent Mental Health: A Handbook, edited by C. Jackson, K. Hill, and P. Lavis. Brighton: Pavilion Publishing.

Kaźmierska, Kaja. 2019. “Winners and Losers of the Process of Transformation as an Etic Category versus Emic Biographical Perspective." Qualitative Sociology Review 15(4):238-266. Retrieved Month, Year (http://www.qualitativesociologyreview.org/ ENG/archive_eng.php). DOI: http://dx.doi.org/10.18778/1733-8077.15.4.11 